$\begin{array}{ll} & \text { Etnográfica } \\ \text { etnográfica } & \text { Revista do Centro em Rede de Investigação em }\end{array}$

Antropologia

vol. 11 (2) | 2007

Vol. $11(2)$

\title{
Questioning locality: the UBC Museum of Anthropology and its hinterlands
}

Questionando a localidade: o UBC Museum of Anthropology e os seus arredores

\section{Anthony Shelton}

\section{OpenEdition}

\section{Journals}

Electronic version

URL: https://journals.openedition.org/etnografica/2025

DOI: 10.4000/etnografica.2025

ISSN: 2182-2891

\section{Publisher}

Centro em Rede de Investigação em Antropologia

\section{Printed version}

Date of publication: 1 November 2007

Number of pages: 387-406

ISBN: 0873-6561; E-ISBN 2182-2891

ISSN: 0873-6561

\section{Electronic reference}

Anthony Shelton, "Questioning locality: the UBC Museum of Anthropology and its hinterlands", Etnográfica [Online], vol. 11 (2) | 2007, Online since 27 September 2012, connection on 11 February 2022. URL: http://journals.openedition.org/etnografica/2025 ; DOI: https://doi.org/10.4000/ etnografica.2025

\section{(c) (1) (8)}

Etnográfica is licensed under a Creative Commons Attribution-NonCommercial 4.0 International License. 


\title{
Questioning locality: the UBC Museum of Anthropology and its hinterlands ${ }^{1}$
}

\begin{abstract}
Anthony Shelton
This paper argues that locality is itself a culturally constructed category which, if not critically assessed may hide the political relations existing between museums and other institutions within a specified museumscape. Frequently, museums, as in the case of British Columbia, operate at local, national and sometimes regional levels. While acknowledging the importance of studies on the poetics of museum exhibitions and display, critical museology cannot discount the political and historical contexts under which museums operate or omit analysis of the ideologies with which they are enshrouded.
\end{abstract}

KEYWORDS: museums, politics, locality, regionalism, Vancouver, British Columbia.

\begin{abstract}
JAMES CLIFFORD'S 1997 COMPARISON OF MUSEUMS AND CULTURAL centres in British Columbia broke new ground in examining how such institutions work within a specified and discrete cultural and geographical field. Instead of dividing and examining museums or cultural centers individually according to history, size, resources and/or espoused mission, as has often been the norm, he compared the poetics of their exhibitions and speculated on their regional political situation to redirect attention to the wider field of institutional representations of which they were part. This paper is intended to complement Clifford's earlier work by focusing on some of the political conditions and issues surrounding museums in the Canadian Northwest. Such a consideration however, raises questions about categorizing museums as "local"
\end{abstract}

l The author is Director of the University of British Columbia's Museum of Anthropology and Professor of Anthropology at the same University. The approach taken in this paper has been broadly influenced by the work of Pierre Bourdieu and Edward Said. 
and it is argued that "locality" itself is a culturally constructed idiom that can hide the more complex and overarching relations that such museums often have with wider national and regional organizations, governing and financial bodies, and other diverse interests.

\section{THE FIELD OF NORTHWEST CANADIAN MUSEOLOGY}

In 1988, while teaching a summer institute in Vancouver, Clifford examined two coastal cultural centres, the U'mista Cultural Centre at Alert Bay and the nearby Kwagiulth Museum at Cape Mudge, as well as the Vancouver based Museum of Anthropology (MOA) ${ }^{2}$ and the Royal British Columbia Museum (RBCM) headquartered in the provincial capital of Victoria. Three of the four institutions were founded at approximately the same time; the Museum of Anthropology in 1976, the Kwagiulth Museum in 1979 and U'mista in 1980, while the forth, the RBCM, founded in 1886, belonged to an earlier museum age.

Clifford argued the RBCM displays, in their use of documents (texts, photographs, oral histories), mannequins and ethnographic reconstructions and survey techniques based on ethnographic typologisations (ceremonial objects arranged by tribe), were intended to present a comprehensive account covering environmental adaptation, technology, history, anthropology, cultural diversity and current conditions of the First Nations of British Columbia. This historical and ethnological survey impressed Clifford by the unusual attention it gave to the conflicting relations between settlers and First Nations, the calamitous effects of disease and current inequalities resulting from the slow progress of the treaty process (Clifford 1997: 113).

This didactic synthesis of First Nation history and culture delivered in a "black box" environment, he saw as the opposite of the University of British Columbia's Museum of Anthropology. The Museum, surrounded and nestled within its carefully recreated manicured pre-contact flora, high above the sea with panoramic views to the Strait of Georgia, Bowen Island and the snow peaked mountains of the northern mainland, in one sense has created its own local (Kisin 2006: 65). On entering the Museum's atrium and looking down the ramp, the monumental sculptures exhibited in the Great Hall are clearly visible, stepping out on both side of the solid glass wall to the back of the building. Its architect, Arthur Erickson, deliberately reversed many of the architectural presuppositions on which museums had been designed. He transferred the predictable monumentality of exterior facades into powerful and simple alignments and scales of interior spaces and ensured, by planting trees

2 For brevity I shall use the following acronyms: Museum of Anthropology (MOA), Royal British Columbia Museum (RBCM), University of British Columbia (UBC). 
and shrubs at the entrance and incorporating a huge glass wall at the back of the building, visitors transited from a darkened outside into a light interior. The Great Hall forms part of a circuit, notable for its lack of petitioned spaces, that seamlessly connect the other galleries and the large visible storage area that held nearly one third of the Museum's research collections (13.000 objects). For Clifford, MOA celebrated the monumental, the miniature and aesthetic quality of Northwest Coast art, as showcased in its Great Hall, the former Masterpieces Gallery (closed, 1997), and in what is now the Bill Reid Rotunda (renewed 2005). His contention that labels, in the main were sparse and terse leaving nothing to detract from the aesthetic experience, is currently only applicable to the Great Hall. Although aesthetic effect may have been the goal of the architect it is less clear whether it was accepted by the Museum's successive directors and curators. Indeed, there has been a longstanding debate that has taken place since the Museum's opening between those opposed to prescriptive labeling, including the former director, Michael Ames, and others who have long requested explanation of the objects exhibited there. On the other hand, aesthetic effect was, according to the art historian Serge Guilbaut (personal communication), encouraged by Ames in order to place Northwest Coast art on par with that of the West.

Outside the glass wall overlooking the sea and mountains are Haida and Kwak waka'wakw poles and Haida houses carved and constructed by Mungo Martin, Bill Reid, Doug Cranmer and Henry Hunt in 1962 and moved to their current location two decades prior to Clifford's visit. In 1997 two Musqueam houseposts carved by Susan Point were commissioned and erected to frame the entrance into the outside complex. Contemporary works were exhibited in the visible storage area (closed 2006-2009) and rotated in the Theatre Gallery (closed 2006). Visible Storage, where objects arranged by Murdock's cultural area classification, intended for teaching and to encourage scholarly research were displayed, were correctly interpreted by Clifford as a counterpoint to the aesthetic presentation elsewhere in the Museum. Clifford also recognized their public appeal: "Drawers full of small pieces provoke an intimate sense of discovery, the excitement of an attic rather than the staged sublimity of great art" (Clifford 1997: 117). For Clifford, far from reducing art to its aesthetic function: "The museum displays its works of art as part of an inventive process, not as treasures salvaged from a vanished past" (ibid.: 115).

The two tribal museums, Clifford suggested, shared their visual language with those of their larger urban counterparts, but differed in their textual interpretations. The Kwagiulth Museum, with its emblematic spiral like exterior, representing a sea snail, is "clean lined, brightly lit, uncluttered" (Clifford ibid.: 123). The objects on display, excluding monumental carvings, were enclosed in glass cases, similar to the exhibition strategies found at MOA. It's aesthetic 
however was subordinated to its role as repository of family owned properties with label text written in the present tense and bearing the names of each item's current owners. As Saunders acknowledged the visual and textual languages used here were capable of triggering multiple, overlapping and sometimes contested recollections of the past (Saunders 1995: 42-43).

U'mista at Alert Bay differed from the Kwagiulth Museum, by using a visual language not dissimilar from that of the RBCM. Enclosed behind a painted façade resembling a traditional long house, Clifford saw the U'mista Cultural Centre as the most determined to reclaim and recontextualise its collections according to its own view of their significance and history. Historical treatment was specific; it was complex and contradictory depending on its tellers, and demanded that the viewer make connections to bring together disparate threads that told a "local history of appropriation and reclamation" (Clifford ibid.: 137).

In both "tribal" memory houses, objects signified one thing to external noncommunity visitors but something different to the living First Nation community that exhibited them. Gloria Cranmer Webster, the founder of U'mista denied her institution intentionally opposed itself to other museum interpretations, though Cliffford argued that it told a very different, specific, local and unique history that emphasized multiple narratives that were the opposite of the Royal British Columbia Museum's use of a single objectively structured chronological time line (Clifford ibid.: 137). Saunders is more prescriptive still, arguing that the textual exegesis at U'mista was written to shame it's outside visitors, just as the collections seizure had historically been intended to humiliate the community from which it was taken (Saunders 1995: 41).

Although Clifford does not explicitly consider the internal power relations and different political integrations of the four institutions, he nevertheless correctly credited their distinctiveness to their proximity and continual engagement with the region's First Nation communities and surmised that a new type of museology might be taking root there (Clifford ibid.: 109-10).

The most innovative legacy of Clifford's article is its treatment of British Columbia as a field of intersecting, often connected institutions with disjunctured, sometimes complimentary, often differently nuanced narratives based on established museological techniques and strategies. Such narratives are not static as traditional classifications would have them, but as Clifford implied, they reflect changing power relations and competing articulations of local and global meaning. Having had museums forced upon them as a condition of metropolitan museums repatriating their collections, U'mista and the Nuyumbalees societies have rearticulated their functions and reappropriated their regalia within the terms of their own cultural idioms. The stories told by MOA and the RBCM have been framed, more often than not, through deep and sustained engagement with First Nations. Taken together, Clifford concluded, the 
four institutions told four partial stories, none complete, none authoritative, but constructed from different angles and illuminating different perspectives (ibid.: 110).

\section{RE-IMAGINING AN IMAGINARY PROVINCE}

Clifford's description of Northwest museology needs to be complimented by refocusing attention to the historical development of museums and cultural centers and the different political contexts that have helped determine their exhibitionary poetics. In Clifford's text, time is subsumed into simultaneously existing spatial fields and an everyday definition of "locality" was accepted without questioning either its constituent nature or its relation to the space it had been defined in opposition against (Said 1991: 8). This section attempts to situate the specific quality of Northwest Coast museology as the product of each museum or cultural centre's unique experience of history and its confrontation and negotiation of a cluster of related master narratives ubiquitous to frontier regions in Canada and elsewhere.

Historically, British Columbia was established as a colonial frontier between the westernmost extension of the British Empire and the Far East, and the expansionist ambitions of its southern US neighbor. It was a peripheral space that provided a defense and a resource base for future exploitation that was defined in opposition to the metropolitan centres of colonial society. After British Columbia became part of Canada in $187 \mathrm{l}$, the majority aboriginal people continued to be denied political representation and title to ancestral land and were sharply restricted from access to marine, forest and other resources. Because the Federal government assumed responsibility for First Nations and their lands, the Province was able to deny and ignore the problem of indigenous rights and representation and reallocate and lease land to settlers and later the nascent resource industries. Alienation of the First Nation resource base and political marginalization was accompanied by repeated and unsuccessful attempts at their acculturation into the emerging capitalist society. Epidemics and the social and economic conditions resulting from exclusionary policies reduced the aboriginal population by around $80 \%$. This real and symbolic violence was codified and legitimated by the 1857 Act "to encourage the gradual civilization of the Indian tribes in the Canadas" and the 1876 Consolidated Indian Act that fragmented First Nation's political efficacy by imposing the band system of administration, criminalizing the potlatch, the heart of the traditional social and political system, and forcefully removing children from their families to attend residential schools where they were forbidden to speak their native languages.

Colonial survey technologies split the Province's geography between Indian and settler spaces (Harris 2003: 138). By the period 1880-1898 the Indian 
Reserve Commission, had fixed most of the basic internal boundaries dividing cultural groups into more than 1.500 small sized scattered reserves that lacked sufficient resources to provide a minimal degree of sustenance for those that lived on them. Small reserves forced native people to depend on a combination of strategies based on the remnants of the earlier regional economy and the emerging industrial economy for their survival. Forced exposure to the latter promoted the adoption of Christianity and new moral values (Harris 2003: 137-138). With increasing pressure from settlers for agricultural land the federal and provincial government agreed in 1921 to a Royal Commission to examine the size of reserves, which, while recommending a small increase, overall advocated further reductions in their acreage. A special joint committee of Parliament was established in 1927 to examine issues around land titles and treaty demands. Not only did it again dismiss the issue, but it was followed by new legislation that made it illegal for First Nations to raise or spend money to advance their claims over legal title. These political strategies ensured that only $0,33 \%$ of provincial land held by the federal government was divided between First Nations, leaving the remainder to be leased for commercial exploitation.

By holding most British Columbian land as crown land under public ownership, colonial and neo-colonial discourse obfuscated the existence of the internal borders that divided reserve aboriginals from other aboriginals and aboriginals from settlers as well as their attendant surveillance technologies for policing this fragmented territorial patchwork. Not until $195 \mathrm{I}$ did Parliament repeal the law against the potlatch and again permit First Nations to pursue land claims issues. Nevertheless, throughout the decades of the 50s, 60s and 70 s the Province continued to deny the existence of First Nation title, refusing negotiation while seeking to end the debacle through acculturationist policies. Growing public knowledge, interest and sympathy and a number of favourable court actions finally created a more reconciliatory attitude in the 1980s. Not until 1990s however, did the Provincial Government agree to meet with the Federal Government and First Nation leaders to develop a process to begin serious negotiations on legal title and treaty rights.

Not surprisingly, such conditions radicalized British Columbia's indigenous population and led to marked ethnic stereotyping in the majority society. Not for nothing does Loretta Todd, the First Nation film maker and theorist, insist: "Neocolonialism lives, in the boardrooms, classrooms, art galleries, theatres, cinemas, and of course the museums, and public amusement parks" (1994: 303). More directly perhaps Lawrence Paul Yuxweluptun, another First Nation artist made the same point somewhat differently; "I am tired of your usufructurary rights, I am fed up with being a usufruct person. I am tired of being fruct around by all of you. I would like to see all First Nations people have selfgovernment and be able to protect their rights as aboriginal people" (1995-6: 27). Museums, for First Nation people, are implicated in ethnocide and the 
imposition of a Euro-American model of civilization on them. Museums are charged with having confiscated their cultural artifacts and having reduced and domesticated the representation of their conditions of life to the selective majority narrative of cultural extinction and Western progress that are reproduced untiringly through public culture, state ceremonies as well as the arts media, popular literature, small town festivals and local museums (Furniss 1997/8: 7-8). These ideological forms coalesce to create the "cultural myth" of the frontier that has become "condensed and standardized into a core set of narrative structures, symbols, metaphors, and relationships" that pervade the whole of language and the common-sense rationality we impose on the world (Furniss 1997/8: 9). To adopt the words of Said, the Northwest "is an idea that has a history and a tradition of thought, imagery, and vocabulary that have given it reality and presence in and for the West" (1991: 5). The dominance of this imaginary and selective history in Canadian society over actual social and economic relations is what Wilden described as "a collectively experienced and collectively supported system of mirages" that constrains our behavior (1994: 47). For Loretta Todd too: "Colonialism persists because it pervades the very imagination, the very images of the West. In Canada neocolonialism is systemic. It exists in the very foundations of the cultural institutions, and the imaginations that fuel their development and maintenance" (1994: 303).

Fundamental to the imaginary history of frontier societies is the fiction of an anachronistic, unknown and usually uninhabited, territory intended to tantalize settler opportunism and challenge new emigrants to make the land commercially productive and useful. Indigenous populations, if they were acknowledged at all, were described as primitive, inferior and ripe for civilizing missions, while the land was presented as virginal and fecund ready for commercialization. Scott Watson (1994) has written eloquently on the ideological underpinning and discursive uses to which the landscape paintings of the Group of Seven, usually inscribed as the founders of Canadian art history, have been put in producing an abstracted, empty and predominantly White representations of a wilderness nation. These were local narrative manifestations of a global phenomenon, directed and controlled from far away that lie at the very heart of the classification and definition of local space.

Locality is a cultural construct, though its definition is not limited by the institutions that shape it nor is its production necessarily the sole goal of the museums and galleries that disseminate it. Clearly the geographical classification of topographic space, cannot be equated with culturally produced discriminations of space (Said 1991: 5). Furthermore, in an era of overarching political, judicial economic and social relations and the ubiquity of digital media that integrate locality with the nation, region and global fields, the production of locality as an empirically isolated or qualitatively unique space looses plausibility. What is most distinctive about British Columbia in defining 
its locus are its political institutions, but it is these self same institutions that regulate and control financial flows, the exploitation of the local resource base and arbitrate federal and foreign interests, that most effectively works for the eradication of the local and its subsumption by international capital (Linsley 1991: 226). Vancouver originally developed as a transfer point for natural resources "from interior producers and overseas consumers" and this, to a lesser but still important degree continues to be important today (Delany 1994: 13). Vancouver and Victoria as loci of Provincial political and economic power, can, according to one view, be viewed as parasitic on the rest of the Province; sites where government strategize the exploitation of the Province in concert with multi-national corporations and foreign governments. Together with its lower mainland conurbation, Vancouver and Victoria hold a near monopoly over the commercial, political, educational and cultural resources of the Province besides acting as a nexus in the world system. Vancouver in particular may, as Linsley (1991: 226) and Delany (1994: 14) suggest, have more in common functionally with Los Angeles, Hong Kong and Tokyo than with its interior rural hinterlands. The realization of these unequal and antithetical power relations, axiomatic of situations of internal colonization, has deeply influenced museum displays, and the varied positions local cultural institutions have chosen to support. If they have produced no new exhibition genres, they have accommodated established strategies to unique circumstances resulting in them "both playing and subverting the dominant art-culture game" (Clifford 1997: 108).

\section{THE EMERGENCE OF NEW MUSEOLOGICAL COMMITMENTS}

Trade and colonialism were the first experiences of western modernity for most First Nations and other oppressed indigenous peoples. Even though the distance separating British Columbia from the centre of Empire may have diluted colonialism's coercive and moral influence leading to greater diversification in its local operation, its legacy to the post-Independence period cannot be ignored when considering the region's museums and cultural centres. It was British colonialism that established the RBCM and encouraged the accumulation and centralization of cultural objects within the Province's well-guarded political centre. Moreover, museums throughout British Columbia, and elsewhere have been directly and indirectly beneficiaries of the exploitation of forested lands, mineral and marine resources both through gifts and sponsorship and by the acculturative politics pursued by the colonial and later provincial governments. It would be no exaggeration to note that in some cases, the de-politicization and de-historicisation of the "local" culturscape by museum exhibitions has contributed directly to the obfuscatory fictions that reproduce the social relations on which such institutions are dependent. Furthermore, it 
was reformist and reconciliatory policies in the second half of the Twentieth Century around the former spoliation of First Nation cultural heritage that gave rise to U'mista, the Kwagiulth Museum and other cultural centres up and down the Coast that are now reclaiming their formerly alienated and repressed legacies. The new beginning they symbolize in the minds of First Nation people is clearly illustrated in the names of their indigenous administrative bodies; the "U'mista" Society, from the term used to refer to captives taken from their homes by raiding parties and returned to their community following the payment of ransom or a retaliatory raid, and the Nuyumbaleees Society, entrusted with the administration of the Kwagiulth Museum, referring to "the beginning of all legends". These societies have much wider concerns than those traditionally associated with western museums. In the case of U'mista these include repatriation of historical sources and language study and renovation, and the transmission of such knowledge from generation to generation. In short little more than the reclamation of the Province from the imaginary stage-set its politicians, planners, industrialists and financiers have built to perpetuate its misrecognition.

The critical dissolution of an imaginary majoritarian British Columbia has been aided by legal and governmental reforms. ${ }^{3}$ In addition, First Nation populations increased by $22 \%$ between 1996-2001, and with nearly half living either in urban areas or commuting between them and reserves (Harris 2003: 143) have become more visible. Finally, the sudden impulse to reimagine an imaginary province has come from a realpolitik pursued by the current Liberal Government that clearly sees, if it is to be successful in unlocking the mineral resources of northern British Columbia, building pipelines to bring oil and gas from Alberta and construct and enhance port facilities at Prince Rupert and Kitamaat to ship resources to the Far East, it is imperative to resolve land claims and related grievances.

Museums, galleries and cultural centres within British Columbia are grounded in a politically charged locality where repatriation remains an active process and where contestation over the ownership of land remains largely unresolved (Jensen and Brooks 1991). First Nation critics have been keen to underline the influence of these conditions; Mithlo refers to the period as the "pre-repatriation era" (2004: 743), while Todd characterizes it as "neocolonial" (1994: 303). Greater visibility, cultural revivalism, increased news coverage and politicization clearly discredit the salvage or simple aesthetic paradigm as adequate

3 Key legislation includes the 1988 Multicultural Act; The Report of the British Columbia Claims Task Force (June 1991); The Report of The Canadian Task Force on Museums and First Peoples (1991); the Supreme Court Ruling on Delgamuukw v British Columbia (1997), when oral history was made admissible as evidence, the ruling on the Haida Nation v British Columbia (Minister of Forests), on the right to consult and accommodate First Nations prior to settlement of land claims (2004), and the Kelowna Accord (2006). 
reflections of the Province's vital First Nation heritage. Both the RBCM and MOA have parkland with contemporary big houses and poles, reiterating the live and active indigenous presence. This is even more underlined at MOA, which is only a few kilometers distant from the First Nation community of Musqueam with which it has close relations. Moreover, from its inception MOA defined itself as a "living" museum by designating the Haida house and lecture theatre as performance areas, sponsoring artists to work within the Museum and supporting cultural revivalism throughout the Coast. To operate effectively in such a politically and judicially uncertain climate, museums are clearly unable to search for certitude or employ the confidences of mainstream paradigms and assumptions that persist outside the contact zone. As MOA has frequently found there is at best limited consensus over what a museum is, what it should be, how it should work and how it should best balance its contribution to local cultural communities and universalist concepts of science and aesthetics (Ames 1999; Kisin 2006; Clavir 2002; Holm and Pokotylo 1997).

Since its foundation MOA consciously positioned itself as a supporter of First Nations aspirations. Its first director and the founder of the University of British Columbia's Department of Anthropology, Harry Hawthorn, promoted anthropology as an applied and useful discipline that could serve the people of the Province. On his arrival at the University, Hawthorn visited many First Nation communities and shortly after, in 1948, he organized a conference on "Native life, livelihood, schooling, art and welfare" (Hawthorn 1993: 6). Together with his 1958 publication, The Indians of British Columbia: A Study of Contemporary Social Adjustment (with C. Belshaw and S.M. Jamieson) and his influential Survey of the Contemporary Indians of Canada (1966-67) he was a founding architect of the concept of "citizens plus" - individuals carrying all the rights inferred by Canadian citizenship but additionally acknowledged as the bearers of ancient traditions that pre-existed European colonization. Harry Hawthorn remained director of MOA until 1974, when his former student Michael Ames succeeded him. After moving the Museum from its old home in the basement of the library to Arthur Erickson's new building, Ames followed a program guided: "By drawing on its reservoir of its tradition and extending it into new dimensions" (ibid.: vi). This political commitment has been accepted and developed by subsequent directors and made into one of the defining hallmarks of the institution.

\section{RE-IMAGINING LOCALITY; THE FALLACY OF THE LOCAL MUSEUM}

Since Clifford first visited the Coast, significant changes have occurred in the national and provincial Canadian museumscape. While central Canada has recently experienced a museum boom, the West, at the time of writing, has received funding for only one large-scale urban museum project, the refurbishment 
and expansion of the Museum of Anthropology. ${ }^{4}$ Clifford's essay and the success of the institutions themselves have provoked a new field of discourse, much of which is focused on the four institutions he helped to become better known. ${ }^{5}$ These later works have disclosed further surprising institutional convergences and divergences both towards and against the national mainstream models, and have reaffirmed the complexity of the issues institutions have had to negotiate.

The RBCM, following an ambitious temporary exhibition program, has become a more integrated global institution, and while the displays described by Clifford are largely unchanged, plans are under development for a major refurbishment that almost undoubtedly will involve First Nation partnerships. Similar aspirations to host and develop national and international touring exhibitions are also being investigated by MOA and U'mista Cultural Centre.

The two First Nation centers have experienced both success and disappointment. In 1988, the communities celebrated the return of the potlatch collections held by the Royal Ontario Museum in Chief Mungo Martin's big house outside the RBCM. This was followed in 1993 by the return of nine more objects, and in 2002 by sixteen others from the National Museum of the American Indian, Washington DC (U'mista 2005: 14, 25). In 2005 MOA returned three Hamatsa masks, which because of their unresolved identification, were placed on long-term loan to U'mista. Then in 2006 the British Museum placed a Sun transformation mask, previously identified as being part of the potlatch collection, also on extended loan to the Centre, while the Breton family repatriated a mask previously owned by André Breton. These additions to the collection have so far resulted only in a central platform being installed to help accommodate the new material, but insufficient storage and workspace and the desire to extend the gallery and shop and build a performance area require future expansion.

In 2000 the Kwagiulth Museum temporarily closed to the public. Repeated funding crises that had previously been resolved only by the generosity of its board members, finally became insurmountable and, with declining visitor numbers, forced closure (Fortney 2001: 110) until 2007 when, with help from the Canadian Museum of Civilization, it was planned to reopen. Elsewhere,

4 Two First Nation cultural centers have also been funded, the Squamish Cultural Centre and the Haida Museum in Skidegate. There are another eight applications from First Nation communities for cultural centers with the Provincial Government. In addition the RBCM and the Vancouver Art Gallery have expansion and renewal plans, and the Provincial Government has promised up to four new museums for the Province as part of its Pacific Gateway Project.

5 Saunders (1995) on U'mista; Meuli (2001), Fortney (2001) and Mithlo (2004) on U'mista, Kwagiulth Museum and other cultural centers; Frank (2000) on the Royal British Columbia Museum; and Hawthorn (1971; 1993), Elias (1977), Ames (1992; 1999), Phillips (2003), Kisin (2006) and Rossi (2006) on the Museum of Anthropology. 
communities are building (Squamish/Lillooet, Skidegate), planning (Kitamaat, Greenville), or discussing (Musqueam) new cultural centres or museums, sometimes with Museum of Anthropology staff performing advisory roles. At the same time less orthodox sites presenting Northwest Coast art have multiplied in Vancouver and elsewhere; Canada Place Convention Centre, Stanley and Vanier parks, the Vancouver International Airport and ferry terminals at Tsawwassen and Horseshoe Bay. In preparation for the 2010 Winter Olympics and Paraplegic Games, new sporting venues are commissioning local First Nation artists, as are the City's Sky-train network, the University of British Columbia, and the Museum of Anthropology. Such unprecedented activity clearly indicates a city that, in response to international development and capital, having previously celebrated its post-modernity and post-historicism (Delany 1994), is reinventing a "local" appellation through a reconstructed genealogy linking it to First Nation heritage.

In the face of such complex and sometimes apparently paradoxical developments within and between museums and galleries and cultural centres, we must reconsider the meaning and application of the idea of "locality" and the category of "local museums", including the distinction between "tribal" and majority institutions that, more than distinguishing geographical location, also imply differences in their respective worldviews. Having briefly summarized the invention of the characteristics of a provincial localism and its ideological functions, I now shift attention briefly to the political context of the local institutional histories, internal debates and audiences to compliment the previous foci on poetics.

Mithlo (2004: 751-752) has criticized the presumption of opposition between majoriterian and tribal museums denying there ever was a conscious decision to take oppositional stances. Instead majority western museums and First Nation cultural centres should be regarded as examples of alternative museologies. Opposition, she notes, implies the acceptance of a western binary idea that conveys negative associations. In the case of the Museum of Anthropology differences between it and cultural centers may be more about purpose and degree than contentious philosophies. MOA, along with the cultural centres established in the 1960s and 1970s, identified themselves as "living museums". At one level both types of museums/cultural centres have influenced each other. Gloria Cranmer Webster, the former Director of U'mista acknowledged the possible influence of the Museum of Anthropology's open storage philosophy on their own displays (Fortney 2001: 78). Cranmer began her own curatorial career at the Museum of Anthropology under the Hawthorn and it was their son, Henry, who was the architect for both U'mista and the Kwagiulth Museum. Collaboration, along with the mutual influences it often generates is however, more profound and pervasive than this. In the 1950s the Museum of Anthropology, the RBCM and various First Nation artists worked 
together on the British Columbian Totem Pole Preservation Committee, which established both their totem pole collections. The four museums/centers also jointly curated and shared exhibitions and related projects. ${ }^{6}$ First Nation cultural centres have inevitably influenced MOA. The reaffirmation and reclamation of knowledge about the history of First Nations was seen as fundamental for a proper re-engagement with alienated populations. Furthermore the focus on the exhibition galleries doubling as performance and ceremonial spaces directly echo the multiple purposes that First Nation cultural centres serve. In addition to these hybrid influences, MOA like the RBCM loans objects from its collections for ceremonial use in their community's of origin; it regularly arranges purification ceremonies for its collections in compliance with First Nation protocols; with the Laboratory of Archaeology, it acts as a repository for valuable community paraphernalia, fragile archaeological material and human remains; and it acknowledges Musqueam protocols over their traditional territorial rights where it is located.

This is not to say that there are no internal differences within institutions capable of sometimes mobilizing strong external opinions. Some new First Nation centres have been fairly harmoniously developed with commercial and educational purposes well balanced, but Fortney (2001: 66) notes that in others divisions have opened between those who believe the centre no longer provides them the services they once did and others who have been forced to take a more pragmatic economic stance to maintain their operation. At MOA, while Michael Ames personally admired Erickson's building, particularly the versatility of the Great Hall, he nevertheless expressed doubts about its suitability as a First Nations museum; “... a very Western, pristine, cold, concrete building" he called it (Kisin 2006: 64). Erickson, in turn, considered the Museum his greatest work (personal communication 2006). Vastokas, controversially dismissing the First Nation collections as lacking any age, opined “... Erickson's museum building in itself serves more as a monument and a

6 The Kwagiulth Museum, U'mista, MOA and the RBCM curated the exhibition, The Copper that Came from Heaven (1983). U'mista collaborated with UBC to produce the film, Box of Treasures (1980); an oral history project (1994); and the book The Living World, an Ethnobiological Literary Manual (1998), as well as partnering with the RBCM on the exhibition Whales. The Enduring Legacy (1997). Currently, U'mista, along with Musqueam Indian Band and Sto lo Nation and Tribal Council, are co-developers with MOA on the Reciprocal Research Network, an interactive research platform intended to provide a common search engine across digitally held collection data contained in museums in Canada, the US and England. In another project between U'mista's, Kwakwaka'wakw Centre for Language and Culture at Simon Fraser University and MOA, work is underway to provide a digital format through which archival and historical data pertaining to Kwakwaka'wakw traditional territories will be electronically repatriated from libraries and archives across the world. The Kwagiulth Museum was similarly active in collaborative projects with other institutions. It borrowed several exhibitions from MOA including Our Chiefs and Elders (1990-1); Blood from Stone (1990-1); Eulachon - A Fish to Cure Humanity (1993); Inside Passage 1792 (1993), as well as the RBCM, Owls of Canada (1995) (Fortney 2001: 103). 
tribute to Northwest Coast native culture and becomes, thereby, as important as the collections it contains" (1976: 11). Ellipses in indigenous content and meaning of the collections were also noted early on.

Different points of view also existed around curatorial and First Nation authority. Ames was a stalwart supporter of decolonizing museums and returning the voice of interpretation to First Nation and other originating communities. His passion was not shared by all his colleagues (Ames 1999: 46; Kisin 2006: 31). Moreover his political agenda sometimes conflicted with that of the archaeologists in the Anthropology Department concerned over professional issues and academic standards (Kisin 2006: 44-45). Differences between the Museum and the Department of Anthropology and Sociology had already surfaced in the 1970s (Whittaker and Ames 2006: 167), that years later might have provoked Ames' skeptical and ambiguous characterization of the discipline of anthropology as a "devious inquiry" (Kisin 2006: 16).

Two exhibitions intended to reaffirm the importance of collaboration with originating communities that received much written attention, demonstrate well the strengths and limitations of this approach. Written in the Earth (opened 1996) and From Under the Delta (opened 1996) provoked significant disagreements on the comparative value of scholarly and community knowledge and brought to the fore differences over the ascription of authoritative references, differences in political agendas, differences in timetabling, and differences over concept design. Despite such difficulties the exhibitions influenced the re-direction that Ames took to implement the recommendations of the 1991 Task Force Report on which he and Ann Stevenson, the Museum's collection manager, had sat. The two exhibitions generated their own circumspect literature (Holm and Pokotylo 1997; Ames 1999; Philips and Johnson 2003; Kisin 2006), but some points of view remain to be heard. Bruised and battered, after what Ames described as "mumbling and grumbling", MOA opened a new chapter for itself with the implementation of a new type of collaborative research, PAR (participatory action research), in which research is determined by the interests of the community rather than the museum or academic department (Phillips 2003: 160). In the same genre Salma Mawani and Carol Mayer curated The Spirit of Islam (2001-2002), while Pam Brown curated Mehodihi. Well Known Traditions of Tahltan Peoples (2003-5). Accepting the political dimension and ethical interdictions underlying exhibition making, Ames later acerbically remarked: "No one promised that decolonization would be a stroll in the garden" (Ames 2005: 49).

There are other issues and modalities too that have long been debated within MOA; the balance between representing Musqueam and other First Nations, or the balance between First Nation exhibitions, programs, and research and those for the "rest of the world"; the debate between aesthetic and "scientific" styles of display; discussions on whether it is the objects physical integrity that 
is more important or its loan and use to support community ceremonies; the comparative advantages of a "flat" and hierarchical management structure and more recently how far the Museum should embrace a more commercial model; share its management with an advisory committee, and how to program its new temporary exhibition galleries. Such discussions are signs of a vital and committed institution and as Ames opined:

There is more to museums than cannibalistic appetites, glass box display cases, and ideology production. What some call appropriation, others see as inspiration; while some view glass boxes as a form of cultural imprisonment, others see them as a way of preserving heritage for future generations; and what some call the channeling of consciousness, others term consciousnessraising (1992: 4).

Nevertheless, the co-existence of contending points of view within any institution does mean that caution must be exercised when prescribing defining criteria to position institutions within the local/majoriterian dichotomy.

The differences between First Nation worldviews and those of the settler society and their impact on museum policies in British Columbia that Atleo (1991: 48-49) and Mithlo have noted, may be changing as non First Nation administered institutions attempt to become more sensitive and responsive to the ethical commitments incumbent on them. Part of the problem may have been at one level that museums and cultural centers were once too dissimilar for valid comparison. Gloria Cranmer Webster claimed no non-native considerations were taken into account when planning cultural centres (Mithlo 2004: 753). Functions like language preservation, performances, and historical and photographic archives were seldom considered as public functions central to museums, but they are priorities for U'mista and other cultural centres. According to Cranmer Webster "U'mista was never meant to be a museum. Wouldn't we have called it that, if that's what it was going to be? Our Board of Directors said, at the time we incorporated as a registered society, 'We're not building a museum. Museums are for white people and are full of dead things'" (Mithlo 2004: 753).

Rod Naknakim at Point Mudge where the Kwagiulth Museum is located, commented to Fortney that "The Museum is a living thing, not just a place to put objects" (2001: 105), and an elder once told Doreen Jensen that rather than call a new institution she was working on in Hazelton a museum she should call it the Skeena Treasure House explaining "Our culture is not dead, it's only sleeping" (1997/8: 303). Museums still have a long way to go before they are able to treat and show their collections as animate "things" and may only succeed if they place themselves under the closer guidance of First Nations and other originating communities. 


\section{RECONCILIATION AND THE EMERGENCE OF CANADIAN MULTICULTURALISM}

MOA was re-founded, in 1976, in acknowledgement of Canada's cultural and geographical diversity and has grown to promote reconciliation and dialogue over the Province's colonial past and post-Independent internal colonization. It is this reconciliatory project that gives MOA its unique local, provincial, national and international position, as a nexus of diverse spaces and geographies both within and external to Canada. This reconciliatory theme was central to the then President of UBC, D. T. Kenny's, inaugural speech on the occasion of the opening of the Museum's new building on the 30 $0^{\text {th }}$ May 1976.

This museum is a living museum. In a way, it is a house of spirits. Behind the masks, the totems, the ceremonial robes stand the spirits of the human beings who made them. Until we can sense the presence of these spirits and feel the human bond between these people, and ourselves these objects and the people who made them will remain dead. And until they are alive to us, their living children cannot be truly alive for us.

The opening ceremony enacted a form of hermeneutic re-totalization through which the cultures of the Northwest Coast would be placed alongside those of Asia, Pacific and the ancient Mediterranean to be displayed comparatively, symbolizing the abnegation of First Nation's from their provincial solitude and their incorporation into modernity's universal historical narrative. Like the exhibitions, this reconciliation was phrased in the narrative of discovery. In the same speech Kenny emphasized:

So I ask you to consider this museum as a place of discovery. Many things are there to discover. We can discover the thousand beauties left to us by people who lived before us in this beautiful land. We can discover a better understanding of another culture, another way of life. Most of all, if we can learn to see not only the objects, but the spirits dwelling in this house, we can discover a part of ourselves.

Arthur Erickson, the Museum's distinguished architect, shared this attitude:

At this stage in our history, when most forces at work in society dissociative ones, diffracting our knowledge even further, dispersing our energies, fracturing our society, disrupting the ecology of our planet, dismembering our cities, the architect has the opportunity - and I believe the duty, though he seldom seizes it - of being a cohesive force, of providing wholes, "integrities" as Buckminster-Fuller would put it, in a different way. As the 
mechanization of life and man proceeds on its relentless course, we need to reaffirm that which the machines would atrophy in us - the human spirit (Vastokas 1976: 15).

By the mid 1970s the use of a picturesque misrecognition of locality was substituted by the incorporation of the "local" into the universal. In 1967, the Vancouver Museum opened the exhibition, The Arts of the Raven, followed a decade later by the aesthetic presentation of First Nation works at MOA. This humanistic turn was consistent with more general cultural reconfigurations of the notion of Canadian nationhood. The 1976 Canadian Museums Association Conference, "2001: The Museum and the Canadian Public", signaled the beginning of a move away from an object to a human centred museology. In 1992 the $17^{\text {th }}$ General Assembly of ICOM held in Quebec formally endorsed the concept of museums having no boundaries except those that are established by people and encouraged the dissolution of the barriers between them and their communities. This humanistic or new museology, prefigured in Kenny's speech, was consistent with the perspectives that Harry and Audrey Hawthorn had themselves espoused since the museums original foundation in 1947.

"Locality" is an ephemeral and contingent category. MOA is a local museum, but one whose roots have been so deeply implanted in the city and the Province that it is more strongly anchored than most. But it also depends on and contributes to and sometimes contests provincial, national and regional politics and cultural policies. Its exhibitions and programs can be read differently at both the local, regional and international levels. Furthermore, the conditions of locality, as Kisin (2006) has described for two of MOA's exhibitions, have the potentiality of breaking open the closed, finished sense of self identity which is often seen as the hallmark of the local, and creating schisms that provoke radical rethinking of accepted strictures of thought and professional practice. Localisms have a potentially radical charge that can change global presuppositions and patterns of thought. Creativity may sometimes be local, but more often than not it comes from the encounter between the local and another local, national or global condition or representation.

\section{CONCLUSION}

The field of public representations of British Columbia's First Nations is extraordinarily complex. It includes the use of First Nation names, imagery and arts in malls, public spaces, private galleries and street names (cf. Meuly 200 I: 255-256). Even the Canadian/US border is redolent with inflections, special cultural issues, contestations over aboriginal nationalities, rights and freedom of movements, that influence majoriterian cultural procedures (Miller 1996-7: 64). Furthermore, there are many more "tribal" and "majority" museums in 
British Columbia displaying and interpreting First Nation culture than those discussed here. Some like K'san (founded 1968) and the Haida Gwaii Museum at Qay'lloagaay (founded 1976) are older than those Clifford or I have discussed. Others like Xá:ytem Longhouse Interpretive Centre and Secwepemc Museum in the Fraser Valley opened after Clifford's paper had been published. All would call themselves "living institutions". So-called majority institutions such as Campbell River Museum, North British Columbia Museum in Prince Rupert, and Vancouver Museum, as well as the many small town museums, like Williams Lake that Furniss describes in her 1997/8 article, and Kitimaat Museum also point to the complex web of provincial museums and galleries missing from our analysis to date. Furthermore, even when an organization is not publicly open, as was the case of the Kwagiulth Museum, the community does not necessarily consider it closed. What may be important is the organization itself and its purpose in transmitting knowledge from generation to generation independent of the collection's general accessibility. British Columbia not only articulates a web of local, regional and international museum connections, whose leaning to one or other geographical locative may vary over time and depend on external development, but as Michael Ames liked to think, it may also be constituted as a palimpsest, an institutional equivalent of a document on which the tracings of other documents, or institutions, can be evidenced superimposed on the original.

\section{REFERENCES}

AMES, M., 2005, “Museology interrupted”, Museum International, 57 (3), pp. 44-50.

— 1999, "How to decorate a house: the re-negotiation of cultural representations at the University of British Columbia Museum of Anthropology", Museum Anthropology, 22 (3), pp. 41-51.

—, 1992, Cannibal Tours and Glass Boxes: The Anthropology of Museums. Vancouver, University of British Columbia Press.

ATLEO, R., 1991, "Policy development for museums: a First Nation perspective", in D. Jensen and C. Brooks (eds.), In Celebration of Our Survival. The First Nations of British Columbia. Vancouver, University of British Columbia Press, pp. 48-61.

BELL, L., and C. Williams, 1997/8, "Interview with Doreen Jensen BC Studies", The British Columbian Quarterly, 115/6, pp. 289-306.

ClAVIR, M., 2002, Preserving What is Valued: Museums, Conservation, and First Nations. Vancouver, British Columbia, UBC Press. 
CLIFFORD, J., 1997, Routes. Travel and Translation in the Late Twentieth Century. Cambridge, Harvard University Press.

CROSBY, M., 1991, "Construction of the imaginary indian”, in S. Douglas (ed.), Vancouver Anthology. The Institutional Politics of Art. Vancouver, Talonbooks, pp. 267-291.

DELANY, P., 1994, "Vancouver as a postmodern city", in P. Delany (ed.), Vancouver. Representing the Postmodern City. Vancouver, Arsenal Pulp Press, pp. 1-24.

FORTNEY, S., 2001, "First Nations cultural centres in the new millennium: A case study project”, report prepared for the Department of Canadian Heritage, unpublished.

FRANK, G. J., 2000, “'That's my dinner on display': A First Nations reflection on museum culture", BC Studies, The British Columbian Quarterly, 125/6, pp. 163-178.

FURNISS, E., 1997/8, "Pioneers, progress, and the myth of the frontier: The landscape of public history in rural British Columbia”, BC Studies, The British Columbian Quarterly, 115/1 16, pp. 7-44.

HARKIN, M., 1999, "Review essay. From totems to Derrida: Postmodernism and Northwest Coast Ethnology", Ethnohistory, 46.4, pp. 817-830.

HARRIS, C., 2003, Revisiting the Native Land Question, BC Studies, 138/9, pp. 137-151.

HAWTHORN, A., 1993, A Labour of Love. The Making of the Museum of Anthropology, UBC. The First Three Decades 1947-1976. Vancouver, UBC Museum of Anthropology.

HOLM, M., e D. Pokotylo, 1997, "From policy to practice: a case study in collaborative exhibits with First Nations”, Canadian Journal of Archaeology 21 (1), pp. 33-44.

JENSEN, D., and C. Brooks (eds.), In Celebration of Our Survival. The First Nations of British Columbia. Vancouver, University of British Columbia Press.

KISIN, E., 2006, "Memory, Michael Ames, and the Museum of Anthropology: Re-framing collaboration in From Under the Delta and Written in the Earth", honours thesis, Department of Anthropology and Sociology, University of British Columbia.

LINSLEY, R. 1994. "Landscape and literature in the art of British Columbia", in P. Delany (ed.), Vancouver. Representing the Postmodern City. Vancouver, Arsenal Pulp Press, pp. 193-216.

—, 1991, "Painting and the social history of British Columbia", in S. Douglas (ed.), Vancouver Anthology, The Institutional Politics of Art. Vancouver, Talonbooks, pp. 225-246 .

MAUGER, J., and J. Bouechop, 1995, Tribal Collections Management at the Makah Cultural and Research Centre. Washington DC, American Indian Museum Studies program, office of the Museum Program, Smithsonian Institution.

MEULI, J., 2001, Shadow House. Interpretations of Northwest Coast Art. Amsterdam, Harwood Academic Publishers.

MILlER, B., 1996-7, The Really Real Border and the Divided Salish Community. BC Studies 112 , pp. 63-79.

MITHLO, N., 2004, “'Red Man's Burden'. The politics of inclusion in museum settings”, The American Indian Quarterly, 28, 3-4, pp. 743-763.

MORRIS, R., 1994, New Worlds from Fragments. Film, Ethnography and the Representation of Northwest Coast Cultures. Boulder, San Francisco, Oxford, Westview Press.

PHILlIPS, R., 2003, "Introduction”, in L. Peers and A. Brown (eds.), Museums and Source Communities. London, Routledge, pp. 155-170.

ROSSI, E., 2006, Passione da Museo. Florence, Edefin. 
SAID, E., 1991, Orientalism. Western Conceptions of the Orient. London, Penguin Books. SAUNDERS, B., 1995, Kwakwaka'wakw Museology, Cultural Dynamics, 7, pp. 37-68.

TODD, L., 1994, "Neocolonialism lives", in J. Zinovich (ed.), Canadas. New York, Semiotext(e), pp. 303-305.

U'MISTA CULTURAL CENTRE 2005. Kwakwaka'wakw First Nations. 25 Years Celebrating/ Kwakwaka'wakw Culture. Alert Bay, U'mista Cultural Society.

VASTOKAS, J., 1976, Architecture as Cultural Expression: Arthur Erickson and the New Museum of Anthropology, University of British Columbia, Artscanada, 208-209, pp. 1-15.

WHITTAKER, Elvi, and Michael M. Ames, 2006, "Anthropology and Sociology at the University of British Columbia from 1947 to the 1980s", in Harrison, Julia, and Regna Darnell (eds.), Historicizing Canadian Anthropology. Vancouver, University of British Columbia Press, pp. 157-172.

YUXWELUPTUN, L.P., 1995-6, Artist's Statement, BC Studies, 108, pp. 26-8.

Questionando a localidade: o UBC Museum of Anthropology e os seus arredores • Anthony Shelton • Department of Anthropology, University of British Columbia at Vancouver • ashelton@ubc.ca Este artigo defende que a "localidade" é uma categoria culturalmente construída que, não sendo discutida de forma crítica, poderá esconder as relações políticas entre os museus e as instituições num determinado cenário museológico. Tal como é o caso da British Columbia no Canadá, frequentemente os museus operam em registos locais, nacionais e por vezes regionais. Apesar de reconhecer a importância dos estudos sobre a poética das mostras museológicas, a museologia crítica não pode ignorar os contextos políticos e históricos onde os museus operam, nem omitir a análise das ideologias que os envolvem. 